\title{
Scrutinizing two Finnish teachers' instructional rationales and perceived tensions in enacting student participation in mathematical discourse
}

Jennifer Luoto

Department of Teacher Education and School Research, Oslo University, Norway

This study employs interviews and observations to investigate instructional rationales of two purposefully sampled teachers with divergent classroom discourse practices in Swedish-speaking Finnish lower secondary mathematics classrooms. Studies on classroom discourse often point to beliefs and contextual factors shaping teachers' discourse practices. Less is known about how tensions perceived by teachers can influence the instructional rationale in a context such as Finland, known for traditional and teacher-centered mathematics instruction. The findings of this study suggest that these Finnish teachers' instructional rationales for differently enacted classroom-discourse practices are grounded in similar concerns of student needs, related to student learning, well-being, and equity. One of the teachers perceived tension between these concerns and mathematics education literature's ideals of classroom discourse and avoided engaging students in discussions other than in tightly teacher-led format. The other embraced the idea of discourse as facilitating learning and created methods for giving all students equal access to the perceived benefits of mathematical discussions. The identified tensions of student learning, well-being, and equity can be used as guiding principles in developing teachers' discourse practices in professional development in Finland and beyond.

\author{
Article Details \\ LUMAT General Issue \\ Vol 8 No 1 (2020), 133-161 \\ Received 14 April 2020 \\ Accepted 11 June 2020 \\ Published 15 June 2020 \\ Pages: 29 \\ References: 75 \\ Correspondence: \\ j.m.luoto@ils.uio.no \\ https://doi.org/10.31129/ \\ LUMAT.8.1.1329
}

Keywords: classroom discourse, student participation, teachers' instructional rationale

\section{Introduction}

Student verbal participation in classroom discourse e.g., talking mathematics by sharing thoughts and justifying reasoning, is widely recognized as mediating mathematics thinking and learning (Lampert \& Blunk, 1998; Kieran, Forman, \& Sfard, 2001; Franke, Kazemi \& Battey, 2007; Organisation for Economic Co-operation and Development [OECD], 2016a) and positively affecting motivation (Kiemer, Gröschner, Pehmer, \& Seidel, 2015). These ideas of learning mathematics through participating in mathematics discourse are often referred to as sociocultural and Western ideas (e.g., Xu \& Clarke, 2019). They were emphasized in American (e.g., National Council of Teachers of Mathematics, 1989) and some European curricular contexts (see Gravemeijer, Bruin-Muurling, Kraemer, \& Van Stiphout, 2016) as part of a "paradigm shift" away from traditional, teacher-centered approaches and toward 
"reform-oriented" instruction focusing on student engagement and inquiry-based learning (Ellis \& Berry, 2005). This shift has been less prominent in the Finnish context, where instructional practices at the lower secondary level are characterized by teacher-centered instruction and individual seatwork, with scarce opportunities for students to participate in mathematical discussions (e.g., Klette et al., 2018; Taajamo, Puhakka, \& Välijärvi, 2014). In addition, mathematical argumentation has not been a part of the traditional Finnish school mathematics education (Kaasila, Pehkonen, \& Hellinen, 2010), and teachers are viewed as well-established authorities on content knowledge (Pehkonen, Ahtee, \& Lavonen, 2007). Thus, perhaps not surprisingly, participation in mathematics discourse has traditionally not been emphasized in national curricula. However, the latest national curriculum (Finnish National Agency for Education, 2014, pp. 438-441) promotes mathematics instruction that develops students' ability to communicate, interact, and cooperate through presenting and discussing solutions and working in groups as well as individually. Furthermore, the previously high PISA scores-which, in a way, have protected the status quo of traditional instructional practices (see Simola et al., 2017) - are now in decline, while Finnish mathematics educators report a decrease in interest and skills in mathematics in lower secondary schools (Portaankorva-Koivisto, Eronen, Kupiainen, \& Hannula, 2018). It is thus timely to study teachers' instructional rationales and potential tensions that might prevent teachers from prompting discourse among students in a Finnish context. This is important insight for teacher education, as targeting potential tensions that might constrain teachers from discursive practices is needed to develop instruction in line with the curriculum, which also may elevate students' motivation for mathematics (Kiemer et al., 2015). The goal of the present study is therefore to investigate two Finnish teachers' instructional rationale for their differently enacted classroom discourse practices and identify perceived tensions related to enabling discourse among students in lower secondary mathematics classrooms.

\section{Classroom discourse}

Discourse practices in mathematics classrooms are considered contextually bound and collectively developed patterned ways of communicating (e.g., O'Connor, 1998; $\mathrm{Xu} \&$ Clarke, 2013). Yet, classroom interaction research has been able to categorize some generic teacher moves shaping student participation in classroom discourse (e.g., Alexander, 2006; Cazden, 1988; Solomon \& Black, 2008). This study uses the 
categorization of authoritative and dialogic teacher moves by Furtak and Shavelson (2009), building on Mortimer and Scott (2003), to distinguish between teacher moves in which students engage in co-construction of discussions and moves in which the teacher constructs the discussion.

\subsection{Authoritative teacher moves}

Authoritative teacher moves imply information transmissions from teacher to students and are the most common moves in mathematics classrooms (Alexander, 2006). A common pattern associated with authoritative teacher moves is questioning in the pattern called Initiation-Response-Evaluation/Feedback (IRE/IRF) (Cazden, 1988), where the teacher calls for single responses from students, interspersed within longer sections of teacher talk, and student answers often receive short evaluative responses. Other authoritative teacher moves are repeating formulaic phrases and marking significance to help students remember information (Furtak \& Shavleson, 2009), and instruction/exposition, in which the teacher controls the narrative of information, activities, facts, principles, and procedure (Alexander, 2006). In addition, repeated questions and cued elicitation of student contributions are considered authoritative teacher questions, as they lead students to the right answer, also known as a "funneling pattern" (Wood, 1998). A final example of an authoritative move is if teachers promote consensus and select particular student contributions as being correct (Furtak \& Shavelson, 2009), thus puncturing discussions of misconceptions or alternative solutions. All these listed moves are authoritative (Mortimer and Scott, 2003), as such moves facilitate teacher control over the discourse while not inviting students to contribute to shaping the discourse or knowledge construction.

\subsection{Dialogic teacher moves}

Dialogic teaching moves promote discussions and give students opportunities to participate in the construction of knowledge and discourse (Ball \& Bass, 2000). Dialogic teacher moves thus enable what Fennema et al. (1996) call "productive mathematical discourse" that supports inquiry-based learning where students actively grapple with mathematical problems (Artigue \& Blomhøj, 2013). Such teacher moves are open and "real" questions, in which the teacher does not necessarily know the answer, as well as providing neutral responses to student ideas (Furtak \& Shavelson, 2009). Dialogic moves are further in line with a "focusing pattern" (Wood, 
1998), in which teachers prompt students to explain their mathematical ideas. Explaining helps students grasp principles, construct rules for solving problems, and become aware of misunderstandings or lack of understanding as well as develop new understandings (Ingram, Andrews, \& Pitt, 2019). Teachers may re-voice or elaborate on student explanations by using materials to further illustrate ideas or ask for justifications to probe student thinking and direct student contributions to become mathematical (Franke et al., 2009; Walshaw \& Anthony, 2008). Taken together, the dialogic teacher moves thus invite students to shape the discussions and their understanding of content (see Mortimer \& Scott, 2003).

\subsection{Balancing teacher moves}

The authoritative/dialogic dichotomy presented above is useful for describing discourse patterns within classrooms but less useful for judging discourse quality (Drageset, 2015). Both types of moves have their place in mathematics classrooms. Authoritative moves, such as IRE-patterned questions, may be effective in discussions of previously learned content (Temple \& Doerr, 2012), while dialogic moves are beneficial for grappling with new mathematical concepts (Fennema et al., 1996). However, teachers socialize students into ways of thinking and reasoning about mathematics through discourse (O'Connor, 1998), and if teachers use only authoritative moves and never engage students in challenging discourse, students may miss opportunities to develop mathematical reasoning (Cobb \& Bowers, 1999). Several scholars thus recommend that teachers balance authoritative and dialogic moves so that students can both explore ideas and learn relevant content (Boerst, Sleep, Ball, \& Hyman, 2011; Scott, Mortimer, \& Aguiar, 2006).

It is contested whether participation in discourse is equally important for all students. For example, studies show that students may learn just as much by vocal or silent participation in discourse (O'Connor, Michaels, Chapin, \& Harbaugh, 2017), and that participation in discourse is not necessarily beneficial for students with learning disabilities (e.g., Gersten et al., 2009). It is also questioned what type of activity format is most beneficial for student participation in discourse. Traditional whole-class instruction is considered inequitable, as it engages only volunteering students (Emanuelsson \& Sahlström, 2008). While in group work, some group partners are more engaged in discussions than others; hence not all students have the same opportunities to engage in content discussions (Bergem \& Klette, 2010; Webb, Nemer, Chizhik, \& Sugrue, 1998). To establish norms and expectations for social 
behavior in the content-focused discourse, teachers need to pay attention to both social (eliciting contributions from different students) and analytical scaffolding (prompting students to explain reasoning) (Kovalainen \& Kumpulainen, 2005). Consequently, just as teachers need to balance authoritative and dialogic moves, they also need a broad repertoire of techniques for orchestrating classroom discussions that function as productive learning situations for all students (Sfard, 2003; Bergem \& Klette, 2016). Moreover, as the following review suggests, there are several different factors that may shape teachers' instructional decisions about classroom discourse practices.

\section{Teachers' instructional rationale for enacted discourse practices}

Instructional rationale in this study refers to how teachers rationalize their instruction in the complex and situated environment of mathematics classrooms (Confrey, 2017). Similarly to Jeppe Skott's (2001) concept of school mathematics images, instructional rationale is concerned with teachers' idiosyncratic and subjective accounts of their mathematics teaching. Instructional rationale is thus limited to teachers' explicit, avowed, and uttered views of their enacted practices (Fives \& Gill, 2015), in contrast to teacher beliefs, which refer to psychologically held understandings, premises, or propositions about the world that are thought to be true (Pajares, 1992; Philipp, 2007). From the literature, we know that beliefs (e.g., Atweh, Cooper, and Bleicher, 1998; Brendefur \& Frykholm, 2000; Reichenberg, 2018; Sztajn, 2003; Spillane, 2002; Skott, 2001; Pehkonen, 2007) as well as contextual factors (e.g., Ayalon \& Even, 2016; Herbel-Eisenmann, Lubienski, and Id-Deen, 2006; Davis et al., 2019; Raymond, 1997) explicitly and implicitly shape classroom discourse practices. For example, Brendefur and Frykholm (2000) found that beliefs about mathematics and the role of the teacher influence the instructional rationales of teachers' enacted discourse practices in the classroom. The instructional rationale of a teacher with teacher-centered instruction was shaped by beliefs of mathematics as fixed and knowledge as transmissible-believing that learning occurred when students watched examples and listened to explanations. The instructional rationale of another teacher with reform-oriented practices, including group work, was shaped by beliefs that mathematics should be an active endeavor and that mathematics communication facilitated learning and students' construction of knowledge. In a study by Reichenberg (2018), a mathematics teacher rationalized about his preference for 
individual seatwork over discussion-based activities. This teacher stressed that individual work was important for developing higher-order skills and logical thinking, which this teacher considered as non-verbal skills, while he perceived discursive practices in whole-class teaching as mainly promoting verbal skills and lower-order thinking.

Sztajn (2003) and Spillane (2002) in their respective studies demonstrate that teachers' instructional rationales may be related to beliefs about the needs of students with different socioeconomic status (SES); low-SES students are believed to need teacher-centered direct instruction of basic skills, while high-SES students need to be challenged intellectually-for example, through discourse. Similarly, Atweh et al. (1998) suggest that beliefs about other student needs-depending on gender, abilities, and their futures-shape the instructional rationale of teachers. A teacher who saw his male students as high achievers and future mathematicians stressed student independence and self-control of learning, while a teacher who perceived his female students as middle achievers with a future in tertiary studies preferred direct instruction (Athew et al., 1998). In a study by Skott (2001), the teacher enacted different discourse practices depending on beliefs about the main concern for particular students-when the concern was building student confidence, interactions with students were more direct than when the main priority was mathematical learning.

The instructional rationales for discourse practices may also be shaped by tensions and constraints related to contextual factors. In Raymond's study (1997), a large group size, lack of time and resources, and standardized tests were perceived as constraining a teacher from prompting students to engage in discussions. Similarly, Davis et al. (2019) show how a teacher who generally embraced reform-based teaching, perceived tension between reform-based teaching and accountability systems, such as curricula, resources, and expectations from parents and the school. Moreover, Herbel-Eisenmann et al. (2006) found that parents' demands, curriculum materials, and students' own preferences were factors a teacher perceived as constraining reform-oriented teaching approaches. Also, more specific situational factors influence classroom discourse. Ayalon and Even (2016) show that a specific mathematical topic, the specific teacher, and the characteristics of a specific class shaped students' opportunities for diverging into argumentative discussions, stressing that the mathematical topic and the students themselves shape classroom discussions. 
In the Finnish context, empirical research from classrooms is scarce (Simola, 2017) and only a few studies shed light on teachers' instructional rationales of mathematics teachers' discourse practices. For example, in Pehkonen's (2007) interview study on Finnish mathematics teachers' beliefs, teachers implemented teacher-centered methods and the use of textbooks, viewing this as a safe method for delivering content. Kupari (2003), drawing on Trends in International Mathematics and Science Study (TIMSS) survey data, identified how two diverging groups of Finnish mathematics teachers' beliefs reflected their reported practices: the group holding constructivist beliefs embracing understanding as essential for learning were more likely to engage their students in group work than the teachers holding traditional transmissive beliefs. More research is scarcely needed to nuance how such different beliefs may be enacted in classroom practice and instructional decisions in a Finnish context.

In summary, the reviewed studies point to several different factors teachers may perceive as shaping students' participation in mathematics discussions. This study contributes to the field of mathematics education by identifying rationales and possible tensions two teachers with different discursive practices perceive in engaging students in discourse. Situated in a Finnish context, where classroom discourse is not traditionally a part of mathematics education (Kaasila et al., 2010), this study may also nuance the discussion about ideal practices in classroom discourse, as research from different national contexts can contribute to the field by "challenging the relevance of culturally specific evaluative concepts” (Hemmi \& Ryve, 2015, p. 504; Skott, 2019). Knowledge of how teachers rationalize their different classroom discourse practices in a Finnish context may thus inform teacher training and professional development on issues that need to be addressed in order to develop teachers' repertoire of enacted discourse practices. The following overarching research question guided the analysis: How do two Finnish mathematics teachers with diverging practices perceive and enact student participation in discourse? In order to approach this question, three sub-questions were posed:

1. What instructional moves do the two mathematics teachers use to engage students in classroom discourse, and to what extent are these moves used?

2. What is the instructional rationale for the two mathematics teachers' instructional moves in classroom discourse?

3. What kind of possible tensions do teachers with different practices perceive as hindering or enabling student participation in discourse? 


\section{Methods}

\subsection{Participants}

The participating teachers are Anna and Bea (pseudonyms), sampled from the LISA video study focusing on instructional practices in Nordic lower secondary classrooms (see Klette, Blikstad-Balas, \& Roe, 2017). These teachers were purposefully sampled (Patton, 2015), since they displayed contrasting and illustrative patterns of different classroom discourse practices in another study involving eight Swedish-speaking Finnish mathematics classrooms (Luoto et al., in rev). Anna was sampled due to her atypical practice, in which she constantly engaged her students in discussions in various ways. Bea represents a more typical practice, providing few opportunities for students to discuss mathematics. Thus, they represent different types of classroom discourse practices. In this study, I focus on their ninth grade ${ }^{1}$ classes in 2018, when the students are 15 years old. Both teach in schools located in urban, high-SES areas around Helsinki. Anna teaches an "advanced" class, and Bea teaches a "basic" class, but they follow the same curriculum. This kind of tracking was officially discontinued in compulsory education in Finland in the mid-1980s (Pekkarinen \& Uusitalo, 2012, p. 132), as it was considered inequitable. However, the national curriculum allows temporary grouping as a means for differentiation (Finnish National Agency for Education, 2014), and over 50\% of Finnish principals report some form of abilitybased grouping for ninth graders (OECD, 2016b).

\subsection{Video observations}

Three consecutive mathematics lessons from each teacher were video recorded. Two cameras were strategically placed in each classroom, one facing the teacher and one the entire classroom. The teacher wore one microphone, while the other captured student talk. The author was present in the classroom during the filmed lessons, in the role of "observer as participant" - an outsider watching the lesson without intervening (Bernard, 2011). The field notes consisted of pictures of student work and descriptions of tasks and other instructional materials.

${ }^{1}$ The $9^{\text {th }}$ grade is the final year of compulsory school in Finland. 


\subsection{Interviews}

The interviews were semi-structured (Harding, 2013), with mostly open-ended questions on five preselected themes: teachers' perceptions of their own teaching, how students learn mathematics, student participation in general, student participation in discourse in their classroom, and what teachers saw as possibilities and constraints for student participation in discourse (Table 1). The themes in the interview guide were built on the reviewed previous research on beliefs and contextual factors shaping classroom discussions, to broadly include possible factors shaping teachers' instructional rationales. The interview guide was also refined after piloting the interview with two mathematics teachers, to clarify questions that were unclear.

Table 1. Overview of interview themes.

\begin{tabular}{|c|c|c|c|c|c|}
\hline Theme & $\begin{array}{l}\text { 1. Own } \\
\text { teaching } \\
\text { practices }\end{array}$ & $\begin{array}{l}\text { 2. How } \\
\text { students learn } \\
\text { mathematics }\end{array}$ & $\begin{array}{l}\text { 3. Student } \\
\text { participation }\end{array}$ & $\begin{array}{l}\text { 4. Student } \\
\text { participation in } \\
\text { discourse }\end{array}$ & $\begin{array}{l}\text { 5. Possibilities/ } \\
\text { constraints for } \\
\text { student } \\
\text { participation in } \\
\text { CD }\end{array}$ \\
\hline $\begin{array}{l}\text { Example } \\
\text { question }\end{array}$ & $\begin{array}{l}\text { How } \\
\text { would } \\
\text { you } \\
\text { describe } \\
\text { your own } \\
\text { instructio } \\
n ?\end{array}$ & $\begin{array}{l}\text { What } \\
\text { instructional } \\
\text { methods do you } \\
\text { perceive as } \\
\text { important for } \\
\text { your students to } \\
\text { learn } \\
\text { mathematics? }\end{array}$ & $\begin{array}{l}\text { What is student } \\
\text { participation in } \\
\text { discourse in your } \\
\text { classroom? }\end{array}$ & $\begin{array}{l}\text { In what ways do } \\
\text { you encourage } \\
\text { this group of } \\
\text { students to } \\
\text { participate in } \\
\text { classroom } \\
\text { discourse? }\end{array}$ & $\begin{array}{l}\text { Are there any } \\
\text { constraints in } \\
\text { engaging your } \\
\text { students in } \\
\text { classroom } \\
\text { discourse? If so, } \\
\text { what are they? }\end{array}$ \\
\hline Purpose & $\begin{array}{l}\text { To gain } \\
\text { an } \\
\text { overview } \\
\text { of how } \\
\text { the } \\
\text { teachers } \\
\text { perceive } \\
d \text { their } \\
\text { instructi } \\
\text { on in the } \\
\text { classroo } \\
m\end{array}$ & $\begin{array}{l}\text { Investigate } \\
\text { whether and } \\
\text { how teachers } \\
\text { shape their } \\
\text { instructional } \\
\text { practice with a } \\
\text { specific view of } \\
\text { learning } \\
\text { mathematics } \\
\text { (Brendefur and } \\
\text { Frykholm, 2000; } \\
\text { Kupari, 2003; } \\
\text { Reichenberg, } \\
\text { 2018) }\end{array}$ & $\begin{array}{l}\text { Investigate how } \\
\text { teachers perceive } \\
\text { student } \\
\text { participation in } \\
\text { general }\end{array}$ & $\begin{array}{l}\text { Investigate } \\
\text { discursive } \\
\text { practices the } \\
\text { teachers } \\
\text { perceived they } \\
\text { enacted and why } \\
\text { they enacted it } \\
\text { for that particular } \\
\text { class (Ayalon \& } \\
\text { Even, 2016; } \\
\text { Atweh et al., } \\
\text { 1998; Spillane et } \\
\text { al, 2001) }\end{array}$ & $\begin{array}{l}\text { Investigate } \\
\text { possible } \\
\text { constraints } \\
\text { teachers perceive } \\
\text { as hindering } \\
\text { them from } \\
\text { engaging } \\
\text { students in } \\
\text { discourse } \\
\text { (Herbel- } \\
\text { Eisenmann et al., } \\
\text { 2006; Skott, } \\
\text { 2001, Raymond, } \\
\text { 1997; Davis et al., } \\
\text { 2019) }\end{array}$ \\
\hline
\end{tabular}


The interviews were focused (Cohen, Manion, \& Morrison, 2011), targeting the teachers' subjective responses to a situation (their instruction) in which they were involved. In line with focused interviews, some questions were tailored to the observed practice. For example, Anna was questioned about the rationale for her group-work practices, and Bea was questioned about the consistent use of teacher-led whole-class sessions. In general, the questions were posed in the same order to both teachers, while still allowing them to pursue topics important to them (Silverman, 1993). The interviews were audio-recorded, lasted approximately one hour, and took place immediately after the last observed lesson so that the teachers would remember the lessons, thus limiting recall bias. Both interviews were transcribed verbatim.

\subsection{Application and adaptions of the analytical framework}

Furtak and Shavelson's (2009) framework of dialogic and authoritative teacher moves (Table 2), building on a body of previous research (Cazden, 1988; Lemke, 1990; Mortimer \& Scott, 2003; Scott, 1998, and others), served as an analytical lens to facilitate a detailed presentation of teacher moves that enable or constrain student participation. It has previously been applied in other video studies in different subjects (see, for example, Andersson \& Klette, 2016). The framework was applied on classroom discourse episodes (e.g., instances of mathematics discussion in whole class or among peers). This excludes individual teacher-student talk, which is not considered to constitute a joint discussion and understanding of mathematics (Mercer \& Hodgkinson, 2008). Teacher utterances during discourse episodes were coded as authoritative, dialogic, blended, or not applicable. The blended code was applied when a teacher enacted both dialogic and authoritative moves within a single utterance, such as when Anna, in the below example, both controls the narrative by constructing the guidelines and purpose of the group activity (authoritative) and prompts students to discuss mathematics (dialogic).

\footnotetext{
"We will do this task together in groups so you can test what you remember and so I can check that you understand. Discuss within the group. I don't want the person who thinks he or she knows best to respond immediately. Check with each other that everybody knows." (Anna)
}

Some teacher utterances did not fall into any category and were coded not applicable, such as non-content-related questions and comments. These utterances are not included in the results. 
Table 2. Teaching moves (Furtak \& Shavelson, 2009, pp. 183-184)

\section{Dialogic Teaching Moves - Teacher and students jointly construct narrative/discussion}

Asking "real" or open questions.

Spontaneous contributions.

Revoicing/reflecting on student responses.
Teacher asks a question of a student or entire class to which the answer is not necessarily known or expected by the teacher. Students provide unsolicited comments not directly elicited by teacher.

Teacher repeats verbatim what a student has responded without changing or altering the meaning of the statement. Includes when a teacher repeats in a question-style format or asks student to clarify what he or she said or to direct that comment to another student.

Meaning into matter. Teacher uses materials to illustrate or respond to a point or idea raised by student or teacher.

Promoting disagreement / leaving lack of consensus.

Teacher asks students to share divergent ideas and air differences or encourages them to disagree or not reach consensus.

Providing neutral responses to students.

Teacher repeats student responses or provides comments that do not indicate whether student statements are correct or incorrect.

Teacher prompts students to explain to Teacher prompts students to explain their mathematical ideas, peers. strategies, procedures, or concepts to peers.

Teacher encourages students to talk mathematics together.

\section{Authoritative Teaching Moves - Teacher controls course of narrative/discussion}

Cued elicitation of students' contributions.

Teacher asks questions while simultaneously providing heavy clues - such as the wording of a question, intonation, pauses, gestures, or demonstrations-to the information required.

Sequence of repeated questions. Teacher asks the same/similar questions repeatedly to seek a particular answer and continues asking the question(s) until answer is provided by students.

Selecting and/or ignoring students'

Contributions.

Teacher ignores a student's contribution or selects a particular contribution from a chorus of different ideas stated by students.

Reconstructive paraphrase or recap. Teacher recasts or paraphrases what student has said in a more complete or acceptable form or in preferred terminology, including when the teacher adds to or changes the meaning of what the student has said.

Narrative. Teacher lectures or reviews storyline of unit, lesson, or activity or speaks in an uninterrupted flow to students

Formulaic phrases. Teacher uses a particular phrase that is easy for students to remember and repeats it over and over again

Marking significance. Speaking slowly or changing tone so students know that what is being said or what has been said is important

Promoting/establishing a consensus. Providing evaluative responses.
Teacher encourages students to agree or come to a consensus. Teacher clearly indicates, through words or intonation, that a student's comment is correct or incorrect. 
Two additional codes were developed to capture teacher moves specific to peer work: Teacher prompts students to explain to peers and teacher encourages students to talk mathematics together (added as dialogic codes in Table 2). While these can be interpreted as authoritative moves since the teacher controls the activity, they are labeled dialogic here as they prompt student explanations and joint construction of knowledge, which are key indicators of dialogic teaching (e.g., Alexander, 2006). In Figure 1, application of the framework is illustrated in a short excerpt from a lesson about triangles using the software GeoGebra ${ }^{2}$, in which Anna instructs a pair of students to "change two of the points of the triangle while maintaining the same area."

\begin{tabular}{|c|c|c|}
\hline \multirow{2}{*}{$\begin{array}{l}\text { SPEAKER } \\
\text { Student: That's easy }\end{array}$} & \multirow[t]{2}{*}{ CODE } & \multirow[t]{2}{*}{$D / A$} \\
\hline & & \\
\hline Teacher: “Oh? How do you think then?” & Asking real questions & Dialogic \\
\hline \multicolumn{3}{|l|}{$\begin{array}{l}\text { S: "You just change it, so you keep the shape but } \\
\text { at different points." }\end{array}$} \\
\hline $\begin{array}{l}\text { T: "You mean exactly the same shape? Then let's } \\
\text { say you cannot have the same shape. Change two } \\
\text { points and try to think if there is a systematic way } \\
\text { of doing it, do you know anything that could help } \\
\text { you about triangles?" }\end{array}$ & Cued elicitation & Authoritative \\
\hline \multicolumn{3}{|l|}{$\begin{array}{l}\text { S: "The formula for the areal } b^{*} h / 2 \text { [clicks on the } \\
\text { computer]. So, I can change it like this!" }\end{array}$} \\
\hline $\begin{array}{l}\text { T: "Mm, now you can pretend you are a teacher } \\
\text { and tell your partner what you figured out." }\end{array}$ & $\begin{array}{l}\text { Teacher prompts } \\
\text { students to explain to } \\
\text { peers }\end{array}$ & Dialogic \\
\hline
\end{tabular}

Figure 1. Example of coding.

As illustrated above, teacher utterances were coded on the sentence level, and this example shows how dialogic and authoritative moves may be intertwined in teacherstudent interactions.

\footnotetext{
${ }^{2}$ https://www.geogebra.org/about
} 


\subsection{Phases of analysis}

The analysis was performed in four phases. In the first phase, drawing on video observations and field notes, all lessons were viewed several times, transcribed, and mined for identifiable discourse episodes. The focus in Anna's lessons was on triangles (e.g., constructing and calculating angles), and in Bea's, the focus was on exponent rules (e.g., how to simplify and multiply exponents). While the topic of the lessons may encourage different discourse practices, I study these lessons as examples representing different teaching approaches to discourse, and not as a comparison on these two particular teachers (see Section 6.3).

In the second phase, the teacher utterances in classroom discourse episodes were coded using the framework by Furtak and Shavelson (2009) (Table 2), and their frequency counted. These analyses answer the first research sub-question: What instructional moves do the two mathematics teachers use to engage students in classroom discourse, and to what extent?

In the third phase, the interviews were transcribed and analyzed in order to answer the second and third sub-questions: What is the instructional rationale for the two mathematics teachers' instructional moves in classroom discourse? And What kind of possible tensions do teachers with different practices perceive as hindering or enabling student participation in discourse? Two themes were extracted in an iterative process guided by the literature and influenced by the interview guide and the data: perceptions of student participation and perceived factors shaping student participation in classroom discourse. Together, these themes shaped the understanding of the teachers' instructional rationale and possible tensions in engaging students in classroom discourse.

\section{Findings}

Six episodes were identified as classroom discourse episodes: two group-work episodes (10 and 60 minutes) and one whole-class episode (three minutes) in Anna's lessons, and three whole-class episodes, each lasting just under 20 minutes, in Bea's lessons. In the following, the different episodes and discursive moves are described (see detailed results in the Appendix), followed by interview findings of the teachers' instructional rationales. 


\subsection{Anna's classroom discourse practice}

Anna engaged her students in classroom discourse mainly through assigning group work of complex tasks. In Anna's Episode 1, students work in pairs using GeoGebra with triangle tasks. The episode contains 82 dialogic moves, 61 authoritative moves, and nine blended moves. This episode especially provoked the dialogic moves asking real/open questions $(\mathrm{N}=27)$ and spontaneous contributions from students $(\mathrm{N}=26)$ commenting on content or asking Anna questions such as "To construct a perpendicular line-was it like this?" The most common authoritative move by far was narrative $(\mathrm{N}=52)$, manifested in Anna controlling the narrative by guiding and managing group work ("Now I want you to focus on this task").

During group work, Anna frames the rules for participation, illustrated in the following excerpt (lines 3-4) from Episode 2, when she checks in on a peer discussion, requiring all students to be involved in the mathematical discussions. She challenges her students in line with a focusing pattern (Wood, 1998) (lines 6-11), prompting them to explain their mathematical ideas. The task at hand is to figure out whether any of a set of triangles are right triangles.

1 Anna: Maja, you tell me what your group has done.

2 Maja: I didn't have a calculator. I couldn't hear what they said.

3 Anna: Now you [to the group] need to share so that Maja also hears what

4 you are doing.

5 Lotta: We just take $\mathrm{a}^{2}+\mathrm{b}^{2}=\mathrm{c}^{2}$

6 Anna: Yes, and what is that?

7 Lotta: I don't know ... I don't remember

8 Anna: Do you remember, Jani?

9 Jani: I don't know.

10 Anna: Maja?

11 Anna: Why can we use this? Why does it work? I let you think about that.

This example illustrates how Anna balances authoritative and dialogic moves, as she controls the students' discussion, yet uses dialogic moves encouraging students to continue exploring mathematics in their discussions by asking for justifications and prompting students to explain their ideas (Franke et al., 2009).

In Anna's Episode 2, three to four students work in groups on triangle tasks, equipped with a whiteboard, which they use to show their process and solution. In this episode, there is a balance of dialogic $(\mathrm{N}=21)$ and authoritative moves $(\mathrm{N}=20)$; a few moves are blended $(\mathrm{N}=4)$. This episode also provoked asking real/open questions $(\mathrm{N}=9)$ and spontaneous contributions from students $(\mathrm{N}=5)$, while the most common authoritative moves were narrative $(\mathrm{N}=8)$ and providing evaluative responses 
$(\mathrm{N}=8)$. During both group-work episodes, there were a combined 15 instances of the peer-work codes prompting students to explain to peers and encouraging students to talk mathematics.

Anna's Episode 3 is a short whole-class episode summarizing peer work on triangles. In contrast to Anna's first two episodes, this is characterized by authoritative teacher moves $(\mathrm{N}=5)$.

1 Anna: Okay, let's freeze here. All groups have realized that we need to use

2 the Pythagoras' theorem in some way. Some didn't remember its name, but

3 you all knew it. But what is difficult is to know why we use Pythagoras'. I

4 heard at least two groups who could tell why. So, Mia, you can tell me since

5 you knew why do we use Pythagoras' theorem?

6 Mia: Because it only works on a right triangle to find the hypotenuse.

7 Anna: So the requirement for Pythagoras' theorem is that the sum of all

8 the squared lengths is the hypotenuse squared-this formula. In this case it

9 is $\mathrm{a}^{2}+\mathrm{b}^{2}=\mathrm{c}^{2}$. If you know the length of two sides, you can find out the

10 length of the third side, but the whole point here is that this only works in

11 a right triangle, and that is why you can use it to test whether this triangle is 12 a right-angle one.

Anna sums up why the Pythagorean theorem is needed for solving this task by selecting a student contribution she emphasizes as correct, providing an evaluative response (lines 4-5), then paraphrasing what the student said, and lecturing (narrative) on why the Pythagorean theorem works to test whether a triangle is a right triangle (lines 7-12). Such authoritative moves help bring the lesson forward and give all students a chance to recall why a particular method worked (Temple \& Doerr, 2012).

\subsection{Anna's instructional rationale}

Anna is in her fourth year of teaching. She teaches both mathematics and science and actively participates in professional development programs. In the interview, Anna uses the term inquiry-based to describe her teaching. She states that she wanted to move away from patterns "where you just review theory and procedures, and students perform the same procedures individually." She found this "traditional way" lacking in respect to student learning: "I wanted to find a new way of teaching, a way where students would learn more.” According to Anna, her teacher education did not provide tools for teaching mathematics in a way other than the traditional, but she found a like-minded mentor and a network of study friends with whom she shares tasks, ideas, and experiences. Parents have questioned her methods, but she perceives that the 
school leadership and the new curriculum support her way of teaching: "I realized that the people behind the curriculum think the same way as me." The combination of having a network, a mentor, and support in the curriculum and school leadership appears to have given her a sense of having a professional knowledge base and security to continue developing student-engaging and inquiry-based teaching.

Perceptions of student participation. For Anna, student participation in classroom discourse means students engaging in peer discussions around whiteboards, initiated by questions she poses, or students replying individually on digital devices. Anna states that peer work and student engagement in discussions are necessary for teaching inquiry-based and complex problems and that discussions "make them think." But she states that students also must learn how to work productively in groups, as simply placing them into groups does not automatically enhance learning. In the observed lessons, Anna frames student discussions in multiple instances $(\mathrm{N}=15)$ by prompting them to explain to their peers (e.g., checking whether all students in the group follow the discussion) or encouraging them to discuss mathematics (e.g., focusing discussions toward justification of solutions instead of simply providing solutions).

Perceived factors shaping student participation in classroom discourse. Anna mentions both school-based and student-related factors as constraining student participation in classroom discourse. The key school-based factor was the necessity to maintain the same pace as all other ninth-grade classes because they have the same tests, preventing her from longer explorations of a topic, which is similar to curriculum constraints reported by Herbel-Eisenmann et al. (2006). Student-related constraints were social factors, such as balancing equity while simultaneously paying attention to students' well-being and sense of security. Anna perceived the traditional method of students raising hands in a whole-class setting as "only activating the ablest ones." She states that the inquiry-based approach demands active students, which provokes insecurity in some students not used to working on tasks without prescribed procedures: "Some students do not feel safe in my way of teaching; they miss the traditional way." To tackle their insecurity, she explicitly credits such students' performance in front of the class and provides mathematical challenges on all levels so that even the most skilled students sometimes struggle, thus normalizing incorrect answers. Nevertheless, Anna states that some students must be "left alone," as they are so uncomfortable speaking spontaneously in class. Hence, even though Anna embraces the idea that students learn through participating in 
discussions, there seems to be a tension between that and another more pressing concern of certain students' well-being.

\subsection{Bea's classroom discourse practice}

The following example illustrates how classroom discourse in all three of Bea's episodes consisted of long, uninterrupted flows of teacher lecture (lines 10-21), punctuated by short student contributions in IRE format (Cazden, 1988) (lines 7 and 9), with a focus on rules and procedures. Bea reviews a task she has noticed several of her students struggling with. The task is to solve $3 \frac{1}{3}^{-2}$ and it is written on the board.

1 Bea: First, I want to remove the 3, so I multiply 3 with this part of the

2 fraction, $3^{*} 3$, which is $9+1$. I write it as $\frac{10^{-2}}{3}$ Can you see this? Then I

3 look at my rules. I think it was our rule 8 ; look in your notebooks. If I have

4 a negative exponent, what should I do with the nominator and denominator

5 to make it plus, positive? What shall I do with it? Fredrik, what should I do

6 with the 10 and the 3 ?

7 Fredrik: We should solve them.

8 Bea: No, we don't solve them. What did you do, Allan?

9 Allan: You change their positions.

10 Bea: We change their positions. That was our last rule. It is in your books,

11 and we also wrote it down. If I have $\frac{a^{-n}}{b}$, to get rid of the negative here, I

12 can absolutely not put it in front of here with a minus-like put the minus in

13 front of the fraction and then the parenthesis, and then it is good. No, to

14 remove the negative exponent, I change the positions. So b, the

15 denominator, will be up in the nominator, and the old nominator will be

16 the denominator, and then I change from minus to plus. So 3 here, and 10

17 down here, and the parenthesis is from -2 to +2; do you follow? So the

18 next rule, I write here 8 since it is our rule number 8 . Then I use rule

19 number 7 to remove the parenthesis. What shall I do when I have a

20 parenthesis with a nominator and denominator squared? How do I remove 21 it?

In Bea's Episode 1, she reviews exponent tasks and elicits student answers on these tasks in whole-class format. The discursive moves Bea uses include mostly different authoritative moves (87\%), especially narrative $(\mathrm{N}=25)$, providing evaluative responses $(\mathrm{N}=20)$, cued elicitations $(\mathrm{N}=11)$, and sequences of repeated questions $(\mathrm{N}=11)$. Dialogic moves used were students providing spontaneous contributions $(\mathrm{N}=8)$, providing neutral responses to students $(\mathrm{N}=2)$, and asking real/open questions $(\mathrm{N}=1)$.

In Episode 2, almost all moves are authoritative (97\%). Bea reviews a list of exponent rules and occasionally engages students by asking questions in the form of 
cued elicitation, as exemplified in the following excerpt (lines 1-2) when Bea gives Ludde a heavy clue of the right mathematical operation to apply when dividing $8^{13}$ and $8^{11}$.

1 Bea: When we have division between $8^{13}$ and $8^{11}$, it is the same base. What

2 do you think it will be here? If it is not addition, it could be ... Ludde?

3 Ludde: Erhm ... subtraction?

In Episode 3, Bea reviews homework tasks in whole-class format, again guided by mostly authoritative moves (77\%), and the most common ones were narrative $(\mathrm{N}=14)$, providing evaluative responses $(\mathrm{N}=6)$, and cued elicitation of students' contributions $(\mathrm{N}=5)$. The dialogic moves (17\%) consisted of spontaneous student contributions $(\mathrm{N}=5)$ and re-voicing/reflecting on student responses $(\mathrm{N}=3)$.

The following table summarizes the different moves Anna and Bea enacted in their discourse episodes.

Table 3. Overview of teaching moves.

\begin{tabular}{llll}
\hline & Authoritative moves & Dialogic moves & Blended moves \\
\hline Anna Ep 1 & $40 \%$ & $54 \%$ & $6 \%$ \\
Anna Ep 2 & $44 \%$ & $45 \%$ & $9 \%$ \\
Anna Ep 3 & $100 \%$ & $0 \%$ & $0 \%$ \\
Bea Ep 1 & $87 \%$ & $13 \%$ & $0 \%$ \\
Bea Ep 2 & $97 \%$ & $3 \%$ & $0 \%$ \\
Bea Ep 3 & $77 \%$ & $17 \%$ & $6 \%$ \\
\hline
\end{tabular}

\subsection{Bea's instructional rationale}

Bea has been teaching for 30 years in different grades. She has a double degree in mathematics and special education and actively participates in professional development courses and workshops. While colleagues inspire her, she states that the new curriculum has not changed her instruction. Bea describes her instruction in her basic group as different from in a mixed or advanced group: "I explain more and use more everyday language so that they won't get lost." She states that she spends less time reviewing theory in advanced groups, who then have more time for seatwork on difficult tasks.

Perceptions of student participation. For Bea, student participation in discourse means students listening and answering her questions. In Bea's class, verbal participation is voluntary, which she ensures by letting "everyone who raises their 
hands gets to answer." Nevertheless, she appreciates students' questions: "I like when there is discussion among me and the students, when they ask things, not only me answering my own questions." Students' spontaneous questions and comments are also the most common dialogic move observed across Bea's episodes $(\mathrm{N}=6)$. However, the majority of student utterances were short replies given when Bea tried to elicit the right answers to procedural tasks (see above example). Yet Bea also states that students giving the wrong answer is helpful, as she then can try to detangle misunderstandings. In Bea's view, the teacher reviewing content followed by individual seatwork is the most common instructional pattern for her and her colleagues: "I have been a teacher for many years, and I help out in many classrooms, and this is what we all do."

Perceived factors shaping student participation in classroom discourse. Bea remarks on student-related factors as constraining student participation in classroom discourse. In her view, pressing participation in discourse would be detrimental for her students' well-being, as some students have strong negative feelings about mathematics and may have other problems that pressure them. She has agreed with some students to never ask them anything when they are unprepared. For Bea, her most important job as a teacher is to "see my students and let them know that I care," and that is why she prefers to guide and discuss with students individually during seatwork. Another student-related concern is her view of the learning needs of her "basic" students: "Mathematics is a lot about structure and students who have issues concentrating need strict guidance on how to apply rules to not get lost." This resembles results in other studies, where teachers who perceive students as struggling academically or having low future aspirations in mathematics "need" basic mathematics (e.g., Sztajn, 2003; Atweh et al., 1998). Bea thus doubts the learning value of peer discussions in her ninth-grade classroom: "I'm not sure what kind of mathematics these students could discuss. They would discuss everything else but mathematics." Further, she views discussions of complex problems as disadvantageous for struggling students: "I tried it once. It was chaos. Only the highachieving students understood." These statements imply what other studies have highlighted before (e.g., Brendefur \& Frykholm, 2000), which is that beliefs about how students learn and what mathematics is shape instruction, as Bea perceives that these students learn best by listening and that engaging in discourse would be a waste of time. Nevertheless, Bea reflects that the future of mathematics instruction will be different: "I think it will be that you start with a phenomenon or a problem, and then 
you build it up from there. I could never do it with my ninth-graders because everybody has to learn. I would have to guide every one of them. But I think it is the future and a huge challenge for teachers." Thus, while Bea appears to perceive a tension between student participation in discourse and the needs of struggling students, she also recognizes that mathematics teaching and the role of the mathematics teacher is changing in an inquiry-based and discourse-rich direction.

\section{Discussion}

As agreement about the benefits of student participation in mathematics discourse grows (e.g., OECD, 2016a; Walshaw \& Anthony, 2008), national curricula in Finland and beyond are starting to promote such instructional practices. This study scrutinized two teachers' instructional rationales and perceived tensions related to student participation in discourse with the combined analytical foci of teacher perspectives and instructional moves. Findings indicate that the teachers use different discursive moves to engage students. By balancing dialogic and authoritative teacher moves, Anna exemplifies instruction that provides opportunities for all students to participate in what may be called productive mathematical discourse (Fennema et al., 1996). Bea's authoritative moves exemplify instruction where classroom discourse is limited, and student participation means giving short answers in IRE format (Cazden, 1988) and answering cue-elicited questions (Wood, 1998). While their discourse practices varied vastly, their instructional rationales reflected similar concerns. The following discussion will focus on three main concerns reflected in their rationalesstudent learning needs, equity, and student emotional well-being-and how teachers with different discourse practices may perceive them as in agreement or in tension with engaging students in classroom discourse.

\subsection{Instructional rationale for student participation in discourse}

The rationales for the diverging discourse practices seem to be shaped by and grounded in similar values and concerns of student needs, emphasizing student learning, student emotional well-being, and equity. Anna's and Bea's instructional rationales reflected different views of what it means to learn mathematics and what kind of instruction addresses their students' learning needs, a difference often demonstrated in research on beliefs and practices (see Kupari, 2003), including research on different classroom discourse practices (e.g., Brendefur \& Frykholm, 
2000; Sztajn, 2003). Anna's views of learning mathematics were in agreement with the strand of mathematics education research and reform curricula, emphasizing that all students should learn how to think and construct knowledge by discussing (e.g., Lampert \& Blunk, 1998). Bea held more traditional views of learning mathematics and viewed peer discussions as fruitless for struggling students, as she perceived that they needed strict procedural guidance implemented with traditional teacher-centered instruction, similar to the study by Atweh and colleagues (1998). The teachers' different perceptions of student learning needs were also reflected in how they mentioned equity as a motivation for their enacted discourse practices, and they differed in how they sought to facilitate equitable practices. Equitable practice for Anna was activating all students through group work, while for Bea, it was giving all students structure and rules through teacher-centered instruction as well as individual guidance.

While the teachers reflected on different views of student learning needs and how to enact equitable practice, they shared concerns about insecure and shy students never participating in any kind of classroom discourse. They both suggested that mathematics anxiety and out-of-school issues impaired student engagement in discussions, and challenging such students verbally would conflict with attending to student emotional well-being. They had different ways to engage the most insecure students: Anna gave explicit public recognition to insecure students and attempted to normalize wrong answers by asking all students challenging questions, and Bea discussed mathematics privately during individual seatwork, as she perceived that this was how she could attend to unique student needs.

\subsection{Overcoming tensions in engaging students in discourse}

Teachers such as Anna and Bea socialize students to participate in mathematical discussions in very different ways, likely resulting in very different communication skills (O 'Connor, 1998). Anna seems to have embraced the idea of communicative learning for all students, while Bea, though recognizing it as the future of mathematics education, does not seem convinced that such instruction is beneficial for her basiclevel students. Drawing on the literature's ideals of mathematics discourse, the discourse practice represented by Anna, balancing authoritative and dialogic moves, are preferred over the discourse practice represented by Bea, of mainly authoritative moves (e.g., Scott et al., 2006; Boerst et al., 2011). Bea's practice may even be seen as problematic, as participation in discourse is considered to improve learning (e.g., 
OECD, 2016a), as well as motivation (Kiemer et al., 2015). However, Bea's rationale for not engaging low-achieving students in group discussions receives support in research suggesting that peer work does not necessarily benefit the learning of struggling students (Bergem \& Klette, 2016; Gersten et al., 2009). In diverse classrooms, students have different instructional needs, and some teachers, such as Bea in this study, perceive a tension between talking mathematics and student needs. This finding implies a need for more nuance into the discussion that a high degree of dialogic teacher moves and active students in classroom discourse is a goal independent of student characteristics and classroom context, as assessments of classroom discourse should not neglect how contextual factors shape instruction (Skott, 2019). Instead of focusing solely on the beneficial learning opportunities in "talking mathematics," perhaps tensions between dominant discourses in mathematics education literature and local teachers' concerns-such as student learning needs, student well-being, and equity-could be addressed and recognized in teacher education when focusing on practices that enable "productive mathematical discourse" (Fennema et al., 1996). In addition, the different discourse practices that these teachers represent in the classroom, in combination with their different rationales, might be applicable to the rationales of other teachers with similar patterns of practices. To build more knowledge on this topic, I suggest that future research also focuses on how different styles of teaching relates to instructional rationales. Moreover, research on tensions and teachers' concerns and more good examples of instructional practices balancing discursive moves while attending to different students' needs may assist teachers in developing instructional repertoires that allow all students the opportunity to experience learning mathematics while also developing skills to participate in mathematics discourse (see Sfard, 2003). Anna's instructionsupported by the new curriculum, a mentor, a network of colleagues, and school leadership-may give indications of how teachers' classroom discourse practices can address some of the tensions and develop equitable norms for participation. For example, Anna's framing of peer work by scaffolding discourse (Kovalainen \& Kumpulainen, 2005) socially (e.g., checking for equal participation in groups) as well as analytically (e.g., prompting students to explain solutions) shows potential for developing productive norms for student participation in content-related discussions. Such knowledge of how to scaffold discourse is especially important to address in inservice and pre-service teachers in the Finnish context, since the traditional instructional patterns in mathematics education (e.g., Kaasila et al., 2010; Taajamo et 
al., 2014) may not be sufficient to give equitable opportunities for students to develop mathematical thinking and communicative skills or address the decline in student motivation and achievement in mathematics (Portaankorva-Koivisto et al., 2018).

\subsection{Limitations of the study}

Three aspects of this study in particular limit the conclusions that can be drawn; sample size, differences in mathematical content, and ability groups. First, small samples have received criticism for providing understandings that are so contextspecific that they cannot generate any generalizable knowledge (e.g., Richardson, 1996). However, such small case studies highlighting different aspects of teacher rationales build a theory on factors shaping classroom discourse, as shown in the review part (see Chapter 3) of this paper. The short period of three lessons may also be seen as a limitation - however the purpose of this study was not to map out the instructional repertoire of these specific teachers, but to demonstrate different discursive practices. Second and third, the different mathematical content taught (Ayalon \& Even, 2016) and the different ability levels of the students (Atweh et al., 1998) are likely to shape classroom discourse. Regardless of these differences, it is by contrasting the instructional rationales of teachers with differing discourse practices that we can learn about perceived tensions and how teachers deal with them, which in turn may inform teacher educators of issues that are important to address in teacher education and professional development.

\section{Concluding remarks}

The significance of the study lies in its approach to studying the instructional rationale behind different kinds of classroom discourse practices in a Finnish context, which facilitates understanding of possible tensions and perspectives associated with classroom discourse practices. This study has shown that teachers' instructional rationales for differently enacted classroom discourse practices may be motivated by concerns for student well-being, learning, and equity, which some teachers perceive as in tension and contradictive to mathematics education literature's ideals of classroom discourse. This study thus provides nuance for contemporary ideals for mathematics classroom discourse by highlighting how teachers with similar values perceive tensions and find solutions for developing discourse practices, which is an insight that could inform teacher educators in a Finnish context and beyond. 


\section{Acknowledgements}

This study is part of the Linking Instruction to Student Achievement (LISA) study, funded by the Norwegian Research Council (\#222620/F10). I would like to thank my research group SISCO, the rest of the LISA team, and my colleagues Guri and Jelena, for your constructive comments and support.

\section{References}

Alexander, R. J. (2006). Towards dialogic teaching: Rethinking classroom talk (3rd ed.). Cambridge, UK: Dialogos.

Andersson, E., \& Klette, K. (2016). Teachers' use of questions and responses to students' contributions during whole class discussions: Comparing language arts and science classrooms. In K. Klette, O. K. Bergem, \& A. Roe (Eds.), Teaching and learning in lower secondary schools in the era of PISA and TIMSS (pp. 63-84). Cham, Netherlands: Springer.

Artigue, M., \& Blomhøj, M. (2013). Conceptualizing inquiry-based education in mathematics. $Z D M, 45(6), 797-810$.

Atweh, B., Cooper, T. J., \& Bleicher, R. E. (1998). The construction of the social context of mathematics classrooms: A sociolinguistic analysis. Journal for Research in Mathematics Education, 29(1), 63-82. https://doi.org/10.2307/749718

Ayalon, M., \& Even, R. (2016). Factors shaping students' opportunities to engage in argumentative activity. International Journal of Science and Mathematics Education, 14(3), 575-601. https://doi.org/10.1007/s10763-014-9584-3

Ball, D., \& Bass, H. (2000). Making believe: The collective construction of public mathematical knowledge in the elementary classroom. In D. Phillips (Ed.), Yearbook of the national society for the study of education, constructivism in education (pp. 193-224). Chicago, US: University of Chicago Press.

Bergem, O. K., \& Klette, K. (2010). Mathematical tasks as catalysts for student talk: Analysing discourse in a Norwegian mathematics classroom. In Y. Shimizu, B. Kaur, R. Huang, \& D. Clarke (Eds.), Mathematical tasks in classrooms around the world (pp. 35-62). Rotterdam, Netherlands: Sense Publishers.

Bergem, O. K., \& Klette, K. (2016). Conversations as learning tools in mathematics: What do pupils actually learn? In K. Klette, O. K. Bergem, \& A. Roe (Eds.), Teaching and learning in lower secondary schools in the era of PISA and TIMSS. Cham, Netherlands: Springer International Publishing.

Bernard, H. R. (2011). Research methods in anthropology: Qualitative and quantitative approaches (5th ed.). Lanham, USA: AltaMira Press.

Boerst, T., Sleep, L., Ball, D., \& Hyman, B. (2011). Preparing teachers to lead mathematics discussions. Teachers College Record, 113, 2844-2877.

Brendefur, J., \& Frykholm, J. (2000). Promoting mathematical communication in the classroom: Two pre-service teachers' conceptions and practices. Journal of Mathematics Teacher Education, 3(2), 125-153. https://doi.org/10.1023/A:1009947032694

Cazden, C. B. (1988). Classroom discourse: The language of teaching and learning. Portsmouth, USA: Heinemann. 
Cobb, P., \& Bowers, J. (1999). Cognitive and situated learning perspectives in theory and practice. Educational Researcher, 28(2), 4-15. https://doi.org/10.2307/1177185

Cohen, L., Manion, L., \& Morrison, K. (2011). Research methods in education. London, UK: Routledge.

Confrey, J. (2017). Research: To inform, deform, or reform? In J. Cai (Ed.), Compendium for research in mathematics education. Reston, US: National Council of Teachers of Mathematics.

Davis, B., Towers, J., Chapman, O., Drefs, M., \& Friesen, S. (2019). Exploring the relationship between mathematics teachers' implicit associations and their enacted practices. Journal of Mathematics Teacher Education. https://doi.org/10.1007/s10857-019-09430-7

Drageset, O. G. (2015). Different types of student comments in the mathematics classroom. The Journal of Mathematical Behavior, 38, 29-40. https://doi.org/10.1016/j.jmathb.2015.01.003

Ellis, M. W., \& Berry, R. Q., (2005). The paradigm shift in mathematics education: Explanations and implications of reforming conceptions of teaching and learning. Mathematics Educator, 15(1), 7-17.

Emanuelsson, J., \& Sahlström, F. (2008). The price of participation: Teacher control versus student participation in classroom interaction. Scandinavian Journal of Educational Research, 52(2), 205-223. https://doi.org/10.1080/00313830801915853

Fennema, E., et al. (1996). A longitudinal study of learning to use children's thinking in mathematics instruction. Journal for Research in Mathematics Education 27(4): 403-434.

Finnish National Agency for Education. (2014). Grunderna för läroplanen för den grundläggande utbildningen [National core curriculum for basic education]. http://www.oph.fi/lp2016/grunderna_for_laroplanen

Fives, H., \& Gill, M. G. (2015). International handbook of research on teachers' beliefs (Vol. 13). New York, US: Routledge.

Franke, M. L., Kazemi, E., \& Battey, D. (2007). Understanding teaching and classroom practice in mathematics. In F. K. Lester (Ed.), Second handbook of research on mathematics teaching and learning (pp. 225-256). Charlotte, USA: Information Age Publishing.

Franke, M. L., Webb, N. M., Chan, A. G., Ing, M., Freund, D., \& Battey, D. (2009). Teacher questioning to elicit students' mathematical thinking in elementary school classrooms. Journal of Teacher Education, 6o(4), 380-392.

https://doi.org/10.1177/0022487109339906

Furtak, E. M., \& Shavelson, R. J. (2009). Guidance, conceptual understanding, and student learning: An investigation of inquiry-based teaching in the US. In T. Janik \& T. Seidel (Eds.), The power of video studies in investigating teaching and learning in the classroom (pp. 181-205). Münster: Waxmann.

Gersten, R., Chard, D. J., Jayanthi, M., Baker, S. K., Morphy, P., \& Flojo, J. (2009). Mathematics instruction for students with learning disabilities: A meta-analysis of instructional components. Review of Educational Research, 79(3), 1202-1242.

https://doi.org/10.3102/0034654309334431

Gravemeijer, K., Bruin-Muurling, G., Kraemer, J.-M., \& Van Stiphout, I. (2016). Shortcomings of mathematics education reform in the Netherlands: A paradigm case? Mathematical Thinking and Learning, 18(1), 25-44. https://doi.org/10.1080/10986065.2016.1107821

Harding, J. (2013). Qualitative data analysis from start to finish. Los Angeles, USA: SAGE.

Hemmi, K., \& Ryve, A. (2015). Effective mathematics teaching in Finnish and Swedish teacher education discourses. Journal of Mathematics Teacher Education, 18(6), 501-521

Herbel-Eisenmann, B. A., Lubienski, S. T., \& Id-Deen, L. (2006). Reconsidering the study of mathematics instructional practices: The importance of curricular context in understanding 
local and global teacher change. Journal of Mathematics Teacher Education, 9(4), 313345. https://doi.org/10.1007/s10857-006-9012-X

Ingram, J., Andrews, N., \& Pitt, A. (2019). When students offer explanations without the teacher explicitly asking them to. Educational Studies in Mathematics, 101(1), 51-66.

https://doi.org/10.1007/s10649-018-9873-9

Kaasila, R., Pehkonen, E., \& Hellinen, A. (2010). Finnish pre-service teachers' and upper secondary students' understanding of division and reasoning strategies used. Educational Studies in Mathematics, 73(3), 247-261. https://doi.org/10.1007/s10649-009-9213-1

Kiemer, K., Gröschner, A., Pehmer, A.-K., \& Seidel, T. (2015). Effects of a classroom discourse intervention on teachers' practice and students' motivation to learn mathematics and science. Learning and Instruction, 35(C), 94-103.

https://doi.org/10.1016/j.learninstruc.2014.10.003

Kieran, C., Forman, E., \& Sfard, A. (2001). Guest editorial learning discourse: Sociocultural approaches to research in mathematics education. Educational Studies in Mathematics, 46(1), 1-12. https://doi.org/10.1023/A:1014276102421

Klette, K., Blikstad-Balas, M., \& Roe, A. (2017). Linking instruction and student achievement: Research design for a new generation of classroom studies. Acta didactica, 11(3): 1-19.

Klette, K., et al. (2018). "Justice through participation: student engagement in Nordic classrooms." Education Inquiry 9(1): 57-77.

Kovalainen, M., \& Kumpulainen, K. (2005). The discursive practice of participation in an elementary classroom community. Instructional Science: An International Journal of Learning and Cognition, 33(3), 213-250. https://doi.org/10.1007/s11251-005-2810-1

Kupari, P. (2003). Instructional practices and teachers' beliefs in Finnish mathematics education. Studies in Educational Evaluation, 29(3), 243-257. https://doi.org/10.1016/So191491X(03)90012-5

Lampert, M., \& Blunk, M. L. (1998). Talking mathematics in school: Studies of teaching and learning. Cambridge, UK: Cambridge University Press.

Lemke, J. L. (1990). Talking science: Language, learning, and values. Norwood, USA: Ablex.

Luoto, J., Klette, K., \& Blikstad-Balas, M. (in review) Comparing activity formats and instructional patterns in mathematics classrooms: Cases of instruction in Norwegian and SwedishSpeaking Finnish lower secondary classrooms.

Mercer, N., \& Hodgkinson, S. (2008). Exploring talk in schools: Inspired by the work of Douglas Barnes. London, UK: SAGE.

Mortimer, E., \& Scott, P. (2003). Meaning making in secondary science classrooms. Maidenhead, UK: McGraw-Hill Education.

National Council of Teachers of Mathematics. (1989). Curriculum and evaluation standards for school mathematics. Reston, US: NCTM.

O’Connor, C. (1998). Language socialization in the classroom. In M. Lampert \& M. L. Blunk (Eds.), Talking mathematics in school: Studies of teaching and learning in school (pp. 17-55). New Yoork, US: University Press.

O'Connor, C., Michaels, S., Chapin, S., \& Harbaugh, A. G. (2017). The silent and the vocal: Participation and learning in whole-class discussion. Learning and Instruction, 48, 5-13. https://doi.org/10.1016/j.learninstruc.2016.11.003

Organisation for Economic Co-operation and Development. (2016a). Equations and inequalities making mathematics accessible to all. PISA, OECD Publishing. Retrieved from: https://read.oecd-ilibrary.org/education/equations-and-inequalities_9789264258495en\#page 5 
Organisation for Economic Co-operation and Development. (2016b). Selecting and grouping students. In PISA 2015 results (volume II): Policies and practices for successful schools. Paris: OECD Publishing.

Pajares, M. F. (1992). Teachers' beliefs and educational research: Cleaning up a messy construct. Review of Educational Research, 62(3), 307-332. https://doi.org/10.3102/00346543062003307

Patton, M. Q. (2015). Qualitative Research \& Evaluation Methods (4 ed.). Los Angeles: Sage.

Pehkonen, E., Ahtee, M., \& Lavonen, J. (2007). How Finns learn mathematics and science. Rotterdam: Sense.

Pehkonen, L. (2007). To change or not to change. Nordic Studies in Mathematics Education, 12(2), 57-76.

Pekkarinen, T., \& Uusitalo, R. (2012). Peruskoulu-uudistuksen vaikutukset [The reformation of compulsory school]. Kansantaloudellinen aikakauskirja, 2(108), 128-139. Retrieved from https://www.taloustieteellinenyhdistys.fi/images/stories/kak/KAK22012/kak22012pekkari nen.pdf

Philipp, R. A. (2007). Mathematics teachers' beliefs and affect. In F. K. Lester (Ed.), Second handbook of research on mathematics teaching and learning (pp. 257-315). Charlotte, USA: Information Age.

Portaankorva-Koivisto, P., Eronen, L.-., Kupiainen, S., \& Hannula, M. S. (2018). Lukion ensimmäinen ytheinen matematiikan kurssi - mielekästä ja merkityksellistä? [The first common mathematics course in upper secondary - meaningful and worthwhile?]. FMSERA Journal, 2(1), 57-65.

Raymond, A. (1997). Inconsistencies between a beginning elementary teacher's mathematics beliefs and teaching practice. Journal for Research in Mathematics Education, 28(5), 550576.

Reichenberg, O. (2018). Identifying mechanisms of teaching practices: A study in Swedish comprehensive schooling. Scandinavian Journal of Educational Research, 62(2), 213-228.

Richardson, V. (1996). The role of attitudes and beliefs in learning to teach. In J. Sikula, T. Buttery, \& E. Guyton (Eds.), Handbook of research on teacher education (Vol. 2, pp. 102-119). New York, US: Macmillan.

Scott, P. (1998). Teacher talk and meaning making in science classrooms: A Vygotskian analysis and review. Studies in Science Education, 32(1), 45-80.

https://doi.org/10.1080/03057269808560127

Scott, P., Mortimer, E. F., \& Aguiar, O. G. (2006). The tension between authoritative and dialogic discourse: A fundamental characteristic of meaning making interactions in high school science lessons. Science Education, 9o(4), 605-631. https://doi.org/10.1002/sce.20131

Sfard, A. (2003). Balancing the unbalanceable: The NCTM standards in light of theories of learning mathematics. In J. Kilpatrick, G. W. Martin, \& D. Schifter (Eds.), A research companion to principles and standards for school mathematics (pp. 353-392). Reston, US: National Council of Teachers of Mathematics

Silverman, D. (1993). Interpreting qualitative data: Methods for analysing talk, text and interaction. London: Sage.

Simola, H., Kauko, J., Varjo, J., Kalalahti, M., \& Sahlström, F. (2017). Dynamics in education politics: Understanding and explaining the Finnish case: London, UK: Routledge.

Skott, J. (2001). The emerging practices of a novice teacher: The roles of his school mathematics images. Journal of Mathematics Teacher Education, 4(1), 3-28.

Skott, J. (2019). Understanding mathematics teaching and learning "in their full complexity." Journal of Mathematics Teacher Education, 22(5), 427-431.

https://doi.org/10.1007/s10857-019-09446-Z 
Solomon, Y., \& Black, L. (2008). Talking to learn and learning to talk in the mathematics classroom. In N. Mercer \& S. Hodgkinson (Eds.), Exploring talk in schools: Inspired by the works of Douglas Barnes (pp. 73-90). London: SAGE Publications Ltd.

Spillane, J. P. (2002). Challenging instruction for "all students": Policy, practitioners, and practice. JCPR Working Papers 253, Northwestern University/University of Chicago Joint Center for Poverty.

Sztajn, P. (2003). Adapting reform ideas in different mathematics classrooms: Beliefs beyond mathematics. Journal of Mathematics Teacher Education, 6(1), 53-75. https://doi.org/10.1023/A:1022171531285

Taajamo, M., Puhakka, E., \& Välijärvi, J. (2014). Opetuksen ja oppimisen kansainvälinen tutkimus TALIS 2013: Yläkoulun ensituloksia [The international TALIS 2013 study of learning and teaching]. Retrieved from:

https://julkaisut.valtioneuvosto.fi/bitstream/handle/10024/75219/okm15.pdf?sequence=1

Temple, C., \& Doerr, H. (2012). Developing fluency in the mathematical register through conversation in a tenth-grade classroom. Educational Studies in Mathematics, 81(3), 287306. https://doi.org/10.1007/s10649-012-9398-6

Walshaw, M., \& Anthony, G. (2008). The teacher's role in classroom discourse: A review of recent research into mathematics classrooms. Review of Educational Research, 78(3), 516-551. https://doi.org/10.3102/0034654308320292

Webb, N. M., Nemer, K. M., Chizhik, A. W., \& Sugrue, B. (1998). Equity issues in collaborative group assessment: Group composition and performance. American Educational Research Journal, 35(4), 607-661.

Wood, T. (1998). Alternative patterns of communication in mathematics classes: Funneling or focusing? In H. Steinbring, M. G. B. Bussi, \& A. Sierpinska (Eds.), Language and communication in the mathematics classroom (pp. 167-178). Reston, USA: National Council of Teachers of Mathematics.

$\mathrm{Xu}$, L., \& Clarke, D. (2013). Meta-rules of discursive practice in mathematics classrooms from Seoul, Shanghai and Tokyo. ZDM, 45(1), 61-72.

$\mathrm{Xu}, \mathrm{L} .$, \& Clarke, D. (2019). Speaking or not speaking as a cultural practice: Analysis of mathematics classroom discourse in Shanghai, Seoul, and Melbourne. Educational Studies in Mathematics, 102(1), 127-146. 
Appendix. Results: teacher moves*

\begin{tabular}{|c|c|c|c|c|c|c|}
\hline Dialogic moves & Anna Ep 1 & Anna Ep 2 & Anna Ep 3 & Bea Ep 1 & Bea Ep 2 & Bea Ep 3 \\
\hline $\begin{array}{l}\text { Asking real/open } \\
\text { questions }\end{array}$ & 27 & 9 & 0 & 1 & 0 & 0 \\
\hline $\begin{array}{l}\text { Spontaneous } \\
\text { contributions }\end{array}$ & 26 & 5 & 0 & 8 & 1 & 5 \\
\hline $\begin{array}{l}\text { Revoicing/reflecting on } \\
\text { student responses }\end{array}$ & 5 & 2 & 0 & 0 & 0 & 3 \\
\hline Meaning into matter & 9 & 0 & 0 & 0 & 0 & 0 \\
\hline $\begin{array}{l}\text { Promoting } \\
\text { disagreement / leaving } \\
\text { lack of consensus }\end{array}$ & 0 & 0 & 0 & 0 & 0 & 0 \\
\hline $\begin{array}{l}\text { Providing neutral } \\
\text { responses to students }\end{array}$ & 16 & 5 & 0 & 2 & 0 & 0 \\
\hline $\begin{array}{l}\text { Teacher prompts } \\
\text { students to explain to } \\
\text { peers }\end{array}$ & 5 & 2 & 0 & 0 & 0 & 0 \\
\hline $\begin{array}{l}\text { Teacher encourages } \\
\text { students to talk } \\
\text { mathematics together }\end{array}$ & 6 & 2 & 0 & 0 & 0 & 0 \\
\hline Authoritative moves & Anna Ep 1 & Anna Ep 2 & Anna Ep 3 & Bea Ep 1 & Bea Ep 2 & Bea Ep 3 \\
\hline $\begin{array}{l}\text { Cued elicitation of } \\
\text { students' contributions }\end{array}$ & 9 & 5 & 0 & 11 & 4 & 5 \\
\hline $\begin{array}{l}\text { Sequence of repeated } \\
\text { questions }\end{array}$ & 0 & 2 & 0 & 11 & 1 & 1 \\
\hline $\begin{array}{l}\text { Selecting and/or } \\
\text { ignoring students' } \\
\text { contributions }\end{array}$ & 0 & 0 & 1 & 0 & 0 & 0 \\
\hline $\begin{array}{l}\text { Reconstructive } \\
\text { paraphrase or recap }\end{array}$ & 0 & 0 & 1 & 2 & 2 & 0 \\
\hline Formulaic phrases & 0 & 1 & 0 & 0 & 1 & 1 \\
\hline Marking significance & 1 & 0 & 0 & 2 & 1 & 1 \\
\hline Narrative & 52 & 8 & 2 & 25 & 18 & 14 \\
\hline $\begin{array}{l}\text { Promoting/establishing } \\
\text { consensus }\end{array}$ & 0 & 0 & 0 & 0 & 0 & 0 \\
\hline $\begin{array}{l}\text { Providing evaluative } \\
\text { responses }\end{array}$ & 9 & 8 & 1 & 20 & 2 & 6 \\
\hline
\end{tabular}

*This includes overlaps, e.g., blended moves when utterances were coded for both authoritative and dialogic moves 